Journal Of Agriculture and Social Research (JASR) Vol. 6, No.1, 2006

\title{
STOCHASTIC TRANSLOG PROFIT FRONTIER APPROACH TO MEASUREMENT OF PROFIT INEFFICIENCY IN YAM PRODUCTION, IN IMO STATE, NIGERIA.
}

\section{OHAJIANYA D.O., OGUOMA N.N. O AND S.U. ONYEAGOCHA.}

\begin{abstract}
Farm profit inefficiency in yam production in Imo State, Nigeria was estimated using stochastic translog profit frontier model. The mean level of profit inefficiency was 63.7 percent with a wide range of $23.41-94.23$ percent. Mean loss of profit was $N 76061$ per hectare. Major determinants of profit inefficiency were farm size, access to credit, education, family labour use, extension contact and farming experience. Opportunities still exist to reduce profit loss and inefficiency in yam production in the study area if these factors are given the desired attention.
\end{abstract}

Keywords: Stochastic Translog, Profit Inefficiency, yam, Farmers, Imo State.

\section{INTRODUCTION}

Yam (Dioscorea SPP) is widely cultivated as the major fond crop in the mixed cropping system of Imo State. Yam is among the major tuber crops grown exclusively as a human food, and contributes more than 200 dietry calorics cveryday for over 60 million people (Nweke and Ugwu, 1991). Yam is the preferred staple food and it is highly priced for its taste and role in the culture of many people, but the high cost of production makes the per calories cost of yam almost four times the cost of maize (IITA 1988). Farmers in Eastern Nigeria earlier devoted most of their productive resources to the production of yam and less to other crops due to its social and economic importance (Okorji, 1983), current researches indicate that more agricultural resources are now shifted to the production of other crops especially cassava that thrive in poor marginal soils (Ugwu, 1999). The result is that the output of yam which earlier on used to be very high between 1970-1981, has continued to fall below the production figure of other major food crops, and this decline is traceable to inefficient use of resources (Olagoke 1998, Ugwu 1999), resulting to profit loss and low farm income (Afelani, 1998). However, none of these studies investigated the level of profit loss or inefficiency and the determinants in yam production, thereby leaving an information gap which this study was designed to fill. Imo State must strive to reduce the profit loss and inefficiency in yam production so as to retain iit position as one of the largest producers of yam in Eastern Nigeria, and this would only be possible when the determinants of profit loss and inefficiency have been isolated through a study of this naturc. Knowledge of these factors may contribute to the design of programmes to increase the production and profitability of yam production, given existing technology.

Profit inefficiency and how it is measured is an important issue in developing countrics agriculturc. The more recent development of profit function models has allowed the testing of differences in average allocative and average technical efficiency between groups of producers (Yotopoulos and Lau, 1979). However, these models do not provide a numerical measure of farm efficiency (Aigner et al, 1977). This study adopted the approach used by Ali and Flinn (1989) to estimate farm profit inclficiency directly from a stochastic fronticr profit function. Within a profit-function content, profit inefficiency is defined as the inability of a farm to achieve the highest possible profit given the prices and levels of fixed inputs of that farm. 
The stochastic profit function is defined as,

$$
\begin{aligned}
& S_{j}=f\left(P_{i j}, Z_{j}, D_{k j}\right) \text { exp. } e_{j}, j=1,2 \ldots \ldots . . . \ldots \ldots(1) \\
& \mathbf{e}_{\mathbf{j}}=\mathrm{V}_{\mathrm{j}}-\mathrm{U}_{\mathrm{j}}
\end{aligned}
$$

where $S_{j}$ is normalized profit of the $j^{\text {th }}$ farm defined as gross revenue less variable cost, divided by farm specific yam price, $P_{j}$ is the price of the $i^{\text {th }}$ variable input faced by the $j^{\text {th }}$ farm divided by yam price, $Z_{k j}$ is the level of the $k^{\text {th }}$ fixed input on the $j^{\text {th }}$ farm, $D_{j}$ are dummy variables for soil conditions of the $j^{\text {th }}$ farm, $c_{j}$ is an error term, and $j=1,2 \ldots n$ is the number of farms in the sample. $V_{j}$, distributed $N\left(0, \sigma^{2}\right)$ is a two-sided error term representing profit inefficiency in that it measures profit shortfall $\left(S_{t}\right)$ from its maximum possible value $\left(S_{j}\right)$ given by the stochastic frontier. Thus, if $\mathrm{U}_{\mathrm{j}}=0$, the farm lies on the profit frontier, obtaining maximum profit given the prices it faces and levels of fixed factors. If $U_{j}>0$, the farm is inefficient and loses profit because of inefficiency.

\section{MATERIALS AND METHODS}

Yam production is more concentrated in the rural communities of the three agricultural zones of Imo State namely, Owerri, Orlu and Okigwe. Three rural Local Government Areas (LGAs) known for yam production, from the records at the zonal headquarters of the Imo State Agricultural Development Programme (ADP), were purposively selected from each agricultural zone and three communities were randomly selected from each chosen LGA, giving a total of 27 rural communities in the State. The list of yam producers in each selected community compiled with the assistance of the resident extension agent and key informants formed the sampling frame. From this sampling frame, two farmers that cultivated yam in the 2005 crop year were randomly selected from each community, making a sample size of 54 yam producers.

Data were collected from the respondents between March and November 2005, on per hectare basis through a cost-route approach with structured and validated questionnaire. Data were collected on variables such as farm size, labour use, capital, fertilizer use, planting materials other inputs, output and prices, age, household size, education, credit extension contact, co-operative membership, farming experience, family labour use and soil conditions.

\section{Analytical Techniques}

Data were analyzed using the stochastic translog profit frontier model specified as follows; $\pi=f\left(P_{1}, P_{2}, P_{3}, P_{4}, Z, D\right)$ exp. $e_{j} \ldots$ (3)

Where $\pi$ is normalized profit ( ) as defined in equation (I), $P_{1}$ is normalized wage of labour computed as total expenditure on labour divided by total hours of labour; $P_{2}$ is normalized price of seed yam ( $\$$ computed as total expenditure on seed yam divided by total quantity of seed yam planted $(\mathrm{kg}), \mathrm{P}_{3}$ is normalized price of fertilizer (A) computed as total expenditure on fertilizer divided by total quantity of fertilizer applied $(\mathrm{kg}), \mathrm{P}_{4}$ is normalized price of other inputs ( $\mathrm{A}$ ) computed as total expenditure on other inputs divided by total quantity of other inputs used $(\mathrm{kg}), \mathrm{z}$ is depreciated charges on farm implements $(\mathrm{N}), \mathrm{D}$ is soil dummy ( $\mathrm{D}=1$ for good soils conditions and zero for problem saline soils), and $\mathrm{e}_{\mathrm{j}}$ are the error terms defined in equation (2). The model specificd as cquation (3) was first estimated using ordinary least squares (OLS) techniques. The estimates of the partial regression coefficients, and $\sigma^{2}$ were used as starting values for the maximum likclihood Estimation (MLE) of the stochastic translog profit frontier model.

The profit inefficiency of the $\mathrm{j}^{\text {th }}$ farm is given by, $\mathrm{I}-\exp \left(-\mathrm{U}_{\mathrm{j}}\right)$

Profit loss due to inefficiency was then calculated as maximum profit at farm-specific prices, fixed factors and soil dummics multiplied by farm-specific profit inefficiency. 
The second objective of this study was to isolate the determinants of the obscrved profit inefficiency. To achieve this, the following model was formulated and estimated jointly with the stochastic translog profit fronticr model in a single stage maximum likelihood estimation procedure.

$\pi_{\text {in }}=f\left(k_{1}, k_{2}, k_{3}, k_{4}, k_{5} ; k_{6}, k_{7}, k_{8}, k_{9}\right)$.

Where, $\pi_{\text {in }}$ is profit inefficiency per farmer ( $), k_{1}$ is education level (years), $k_{2}$ is access to credit (dummy variable, 1 if there is access to credit, zero otherwise), $\mathrm{k}_{3}$ is household size (No. of persons), $\mathrm{k}_{4}$ is farm size $\left(\mathrm{H}_{\mathrm{h}}\right), \mathrm{k}_{5}$ is co-operative membership (dummy variable, $\mathrm{I}$ for member, zero otherwise), $k_{6}$ is extension contact (No. of visits), $k_{7}$ is farming experience (years), $\mathrm{k}_{\mathbf{8}}$ is fertilizer use $(\mathrm{kg}), \mathrm{k}_{9}$ is family labour use (mandays).

It is expected a priori that $\mathrm{k}_{1}, \mathrm{k}_{2}, \mathrm{k}_{4}, \mathrm{k}_{6}, \mathrm{k}_{7}, \mathrm{k}_{8}, \mathrm{k}_{9}<0$; and $\mathrm{k}_{3}, \mathrm{k}_{5}>0$.

\section{RESULTS AND DISCUSSION}

Estimation of profit function: The OLS and MLE estimates of equation (3) on per hectare basis are presented in table 1. The estimated partial regression coefficients are similar between OLS and MLE models, as expected, the intereept is higher and standard crrors are lower for the MLE estimates. The variance ratio parameter $(\lambda)=\left(\sigma^{2}{ }_{\mathrm{u}} / \sigma^{2} \mathrm{v}\right)$ is statistically greater than zero and comparatively large $(0.95)$, implying that variation in actual profit from maximum profit between farms mainly arose from differences in farmer practices rather than random variability.

The coefficients of the estimated parameters for the variables, labour wage, price of seed yam, price of fertilizer and price of other inputs have the desired negative signs, and are statistically significant at 0.05 level. The implication of this is that if the prices of these inputs in Imo State are reduced far below their present levels, they will significantly reduce profit inefficiency in yam production.

The results obtained for the interaction between labour wage and price of seed yam $\left(\mathrm{P}_{1} \mathrm{P}_{2}\right)$, labour wage and price of fertilizer $\left(\mathrm{P}_{1} \mathrm{P}_{3}\right)$, labour wage and price of other inputs $\left(P_{1} P_{4}\right)$, price of seed yam and price of fertilizer $\left(P_{2} P_{3}\right)$, price of seed yam and price of other inputs $\left(\mathrm{P}_{2} \mathrm{P}_{4}\right)$ show that there is significant negative interaction between these input prices, suggesting that reduction in the prices of these inputs used in yam production would reduce the level of profit inefficiency observed presently.

The coefficients obtained for the interaction between labour wage and soil conditions $\left(\mathrm{P}_{1} \mathrm{D}\right)$, price of seed yam and soil conditions $\left(\mathrm{P}_{2} \mathrm{D}\right)$, price of fertilizer and soil conditions $\left(\mathrm{P}_{3} \mathrm{D}\right)$, and price of other inputs and soil conditions $\left(\mathrm{P}_{4} \mathrm{D}\right)$ show that there is a significant positive interaction between these input prices and soil condition.

TABLE 1. OLS AND MLE ESTIMATES OF PROFIT FUNCTION FOR YAM PRODUCERS IN IMO STATE.

\begin{tabular}{|c|c|c|c|c|}
\hline Variable anc & & & MLE & \\
\hline Important st & Coefficient & t-ratio & Coeffic & ent t-ratio \\
\hline Ln $P_{1}$ & -0.081 & $-2.316^{*}$ & -0.093 & $-2.417^{*}$ \\
\hline $\operatorname{Ln} P_{2}$ & -0.017 & $-2.205^{*}$ & -0.021 & $-2.422^{*}$ \\
\hline $\operatorname{Ln} P_{3}$ & -0.062 & $-2.414^{*}$ & -0.079 & $-2.503 *$ \\
\hline $\operatorname{Ln} \mathrm{P}_{4}$ & -0.039 & $-2.513^{*}$ & -0.042 & $-2.551 *$ \\
\hline $\operatorname{Ln} Z$ & -0.027 & -1.407 & -0.038 & -1.513 \\
\hline D & -0.913 & 1.113 & 0.937 & 1.229 \\
\hline $1 / 2\left(\operatorname{Ln} P_{1}\right)^{2}$ & -0.059 & $-2.689^{* *}$ & -0.061 & $-2.713^{* *}$ \\
\hline $1 / 2\left(\operatorname{Ln} P_{2}\right)^{2}$ & -0.016 & $-3.117^{* *}$ & -0.031 & $-4.802 * *$ \\
\hline $1 / 2\left(\operatorname{Ln} P_{3}\right)^{2}$ & -0.033 & $-2.713 * *$ & -0.038 & $-3.112^{* *}$ \\
\hline
\end{tabular}


Journal Of Agriculture and Social Research (JASR) Vol. 6, No.1, 2006

\begin{tabular}{|c|c|c|c|c|}
\hline $1 / 2\left(\operatorname{Ln} P_{4}\right)^{2}$ & -0.026 & $-2.012 *$ & -0.032 & $-3.499^{* *}$ \\
\hline $1 / 2\left(\operatorname{Ln} Z^{2}\right)$ & -0.059 & -1.109 & -0.071 & -1.304 \\
\hline $1 / 2 D^{2}$ & -0.088 & -1.011 & -0.093 & -1.213 \\
\hline $\operatorname{Ln} P_{1} \quad P_{2}$ & -0.012 & $-2.412^{*}$ & -0.027 & $-2.503^{*}$ \\
\hline $\operatorname{Ln} P_{1} P_{3}$ & . -0.064 & $-2.541^{*}$ & -0.081 & $-2.555^{*}$ \\
\hline $\operatorname{Ln} P_{1} \quad P_{4}$ & -0.059 & $-2.442^{*}$ & -0.073 & $-2.502^{*}$ \\
\hline $\operatorname{Ln} P_{1} Z$ & -0.023 & -1.003 & -0.041 & -1.203 \\
\hline Ln $P_{1} \quad D$ & -0.042 & $-3.019^{* * *}$ & -0.059 & $-3.129^{* *}$ \\
\hline $\operatorname{Ln} P_{2} P_{3}$ & -0.047 & $-2.013^{*}$ & -0.053 & $-2.433^{*}$ \\
\hline $\operatorname{Ln} P_{2} P_{4}$ & -0.091 & $-2.511^{*}$ & -0.095 & $-2.409^{*}$ \\
\hline $\operatorname{Ln} P_{2} \cdot Z$ & 0.032 & 1.152 & -0.041 & 1.326 \\
\hline $\operatorname{Ln} P_{2} \quad D$ & 0.045 & $3.813^{* *}$ & -0.047 & 4. $107^{* *}$ \\
\hline $\operatorname{Ln} P_{3} \quad P_{4}$ & -0.083 & $-2.302^{*}$ & -0.092 & $-2,411^{*}$ \\
\hline $\operatorname{Ln} P_{3} Z$ & 0.072 & 1.427 & 0.083 & 1.522 \\
\hline $\operatorname{Ln} P_{3} D$ & 0.103 & $2.914^{* *}$ & 0.127 & $3.184^{* *}$ \\
\hline $\operatorname{Ln} P_{4} Z$ & 0.015 & 1.602 & 0.031 & 1.445 \\
\hline $\operatorname{Ln} P_{4} \quad \mathrm{D}$ & 0.209 & $3.189 * *$ & 0.245 & $3.892^{*}$ \\
\hline Intercept & 5.213 & 4.117 & 6.209 & 4.703 \\
\hline Log-likclihood & & -147.315 & * & \\
\hline$\sigma$ & & 0.609 & & \\
\hline$\sigma_{u}^{2}$ & & 0.045 & & \\
\hline$\sigma_{v}^{2}$ & & 0.047 & & \\
\hline 2 & & 0.953 & & \\
\hline
\end{tabular}

Source: Computed from survey data, 2005.

The implication of this is that improvements in the quality of soil conditions on which the inputs with the observed expenditure are made would lead to reduction in the level of profit inefficiency in yam production.

Table 2: Frequency Distribution of profit inefficiency in yam production Imo State.

Profit Inefficiency

Range (\%)

$11-20$

$21-30$

$31-40$

$41-50$

$51-60$

$61-70$

$71-80$

$81-90$

$91-100$

Total

Mean profit inefficiency Frequency

Minimum profit inefficiency $11.15 \%$ Maximum profit inefficiency $97.31 \%$ Source: Survey data, 2005.
Relative

7.4

11.1

1.8

3.7

7.4

18.4

35.4

9.2

5.6

54

100.0

\section{$\therefore$ Frequency}


Table 2 shows that the profit incfficiency of yam produccrs range between 11.15 percent and 97.31 percent with a mean of 62.2 percent. Seventy six percent of the yam producers had a profit inefficiency index of above 50 percent. The mean profit inefficiency of 62.2 percent implies high level profit inefficiency in resource use and suggests that opportunities still exist to increase yam production and profit through reduction in profit incfficicncy in resource use by yam producers in Imo State.

Table 3: Frequency Distribution of profit loss in yam production in Imo State, 2005.

\section{Range of Profit Frequency Relative Frequency}

Loss (A /Ha)

\begin{tabular}{lll}
\hline $31000-40000$ & 3 & 5.6 \\
$41000-50000$ & 2 & 3.7 \\
$51000-60000$ & 5 & 9.3 \\
$61000-70000$ & 4 & 7.4 \\
$71000-80000$ & 10 & 18.6 \\
$81000-90000$ & 22 & 40.6 \\
$91000-100000$ & 8 & 14.8 \\
\hline Total & $\mathbf{5 4}$ & $\mathbf{1 0 0}$ \\
Mean profit loss & $\mathbf{N}$ & \\
Minimum profit loss & $\mathbf{N 1 , 0 5 5}$ & \\
Maximum profit loss & & \\
\hline
\end{tabular}

Source: Survey data, 2005.

Table 3 shows that the mean profit loss was $\$ 76061$ per hectare, with a wide range of \$31055 - 91127 per hectare. Majority (40.6\%) of the yam producers incurred a profit loss of $\$ 81000-\$ 90000$ per hectare.

Opportunities still exist to increase the profit levels of most yam producers in Imo State if the factors contributing to profit loss or profit inefficiency are given the desired attention.

\section{Determinants of Profit Inefficiency:}

Table 4 shows that yam producers with more education exhibited significantly less profit inefficiency than those with less education.

Table 4. Determinants of profit inefficiency in yam production in Imo State.

$\begin{array}{lll}\begin{array}{l}\text { Variable } \\ \text { Constant }\end{array} & \begin{array}{l}\text { Parameter } \\ \mathrm{b}_{0}\end{array} & \begin{array}{l}\text { Estimate } \\ 5.299 \\ \text { Education }\left(\mathrm{K}_{1}\right)\end{array} \\ & \mathrm{b}_{1} & (3.106)^{* *} \\ & & -0.052 \\ & (-3.044)^{* *} & 0.039 \\ \text { Credit }\left(\mathrm{K}_{2}\right) & \mathrm{b}_{2} & (2.813)^{* *} \\ & & 0.018 \\ \text { Household size }\left(\mathrm{k}_{3}\right) & \mathrm{b}_{3} & (1.291) \\ & & -0.061 \\ \text { Farm size }\left(\mathrm{k}_{4}\right) & \mathrm{b}_{4} & (-3.077)^{* *} \\ & & 0.073 \\ \text { Co-operative membership }\left(\mathrm{k}_{5}\right) & \mathrm{b}_{5} & (1.525)\end{array}$


Journal Of Agriculture and Social Research (JASR) Vol. 6, No.1, 2006

$\begin{array}{lll}\text { Extension }\left(\mathrm{k}_{6}\right) & \mathrm{b}_{6} & 0.049 \\ & & (2.607)^{* *} \\ \text { Farming experience }\left(\mathrm{k}_{7}\right) & \mathrm{b}_{7} & 0.027 \\ & & (1.629) \\ \text { Fertilizer use }\left(\mathrm{k}_{8}\right) & \mathrm{b}_{8} & -0.066 \\ & & (-2.513)^{*} \\ \text { Family labour use }\left(\mathrm{k}_{9}\right) & \mathrm{b}_{9} & 0.083 \\ & & (3.217)^{* *}\end{array}$

Figures in parentheses are t-ratios

* t-ratios significant at $5 \%$

$* * \mathrm{t}$ - ratios significant at $1 \%$

The negative relationship between education and profit inefficiency is consistent with the findings of Jondrow et al (1982). Large farms exhibited significantly less profit inefficiency than smaller farms, a finding consistent with those of Saleem (1978) and Bravo (1984). Farmers who applied fertilizer experienced less profit inefficiency than farmers who did not use fertilizer. Non-access to credit and inadequate extension services contributed significantly to higher profit inefficiency in yam production.

Farmers who used more of family labour experienced significantly less profit inefficiency, implying that family labour is more economical to use when hired labour is costly.

\section{IMPLICATIONS AND CONCLUSION}

Opportunities still exist to increase yam production and profit in Imo State through increased supply of credit at reduced interest rate and relaxation of insistence of provision of collaterals by lending institutions.

Farmers should be encouraged to attend adult education classes so as to acquire more education. Farmers should also be enlightened on the benefits of use of family labour and fertilizers. The field extension workers should be motivated adequately so as to perform the roles expected of them.

\section{REFERENCES}

Afelani, C.A. (1998). "Economics of Resources Use". A case study of Nigeria Rural Household. The Nigerian Agricultural Journal, Pp. 197-202.

Aigner, D.J.; Lovell, C.A.K and Schmidt, P (1977). "Formulation and Estimation of Stochastic Frontier Function Models". Journal of Econometrics, 6 (I) 21-37.

Ali, M and Flinn, C. (1989). Profit Efficiency among Basmati Rice Producers in Pakistan Punjab. American Journal of Agricultural Economics, Pp. 304-310.

Bravo, M.R. (1984). "Constraints to Cotton Production on Small and Medium farm size levels in South Cotabato". Journal of Agricultural Economics and Development, 14 (I): $57-70$.

IITA (1988). IITA Medium-Term Plan, 1989-1993. IITA Ibadan, Nigeria.

Nweke, F.I and B.O. Ugwu (1991). "Production Cost in the yam based cropping system of Southern Nigeria." Resources and Crop Management Programme, RCMP Research Monograph No.6, IITA Ibadan.

Okorji, E.C. (1983). "Consequence on Agricultural : Productivity of Crop Stereotyping along sex lines". A case study of four villages in Abakiliki Area Anambra State. M.Sc Thesis, University of Nigeria Nsukka. 


\section{Journal Of Agriculture and Social Research (JASR) Vol. 6, No.1, 2006}

Olagoke, A.M. (1998). "Comparative Economics of Resource Use in Rice and yambased crop production in Uzo-Uwani Local Government Area of Anambra State". Ph.D Thesis, University of Nigeria. Nsukka.

Saleem, A. (1978). "Factor inputs and farm productivity on different farms categories in Punjab". Pakistan Development Review, 17 (I); 316-332.

Ugwu, B.O. (1990). "Resource use and productivity in food crops production in major yam production areas of South Eastern Nigeria". Ph.D. Thesis, University of Nigeria Nsukka.

Yotopoulos, P.A. and Lau, I.J (1979). "The Methodological framework". Standford food Resource Institute Studies, 17 (I): 11-12. 